\title{
Association between blood pressure, body mass index, eating habits, and physical activity in adolescents
}

\author{
Associação entre pressão arterial, índice de massa corporal, hábitos alimentares \\ e atividade física em adolescentes
}

\author{
Sandra Aparecida Benite-Ribeiro ${ }^{1} \bowtie$, Viviane Vilela da Silva ${ }^{1}$, Kamila Lauany Lucas Lima ${ }^{1}$, Júlia Matzenbacher dos Santos ${ }^{2}$ \\ 1 Federal University of Goiás, Regional Jataí. Jataí, Goiás, Brazil. \\ 2 Detroit R\&D, Inc. Detroit, Michigan, United States of America.
}

\section{ABSTRACT}

Aims: This study sought to analyze blood pressure and its association with eating behavior, physical activity, and body mass index in high school students.

Methods: A cross-sectional study was performed with high school students from midwestern Brazil. Blood pressure was measured according to the guidelines outlined by the Brazilian Society of Cardiology. Nutritional status was assessed in accordance with the Brazilian Food and Nutrition Surveillance System (Sistema de Vigilância Alimentar Nutricional, SISVAN), according to the standard reference of the National Health and Nutritional Examination Survey (NHANES II), and the level of physical activity was assessed by the International Physical Activity Questionnaire-Short Form. The chi-square test and the Mann-Whitney U test were used for characterization of the population and comparisons between genders and normotensive and prehypertensive subjects. Bivariate and multivariate regression analyses were performed to verify the relationship between blood pressure, physical activity, and eating behavior. The significance level was set at $\mathrm{p}<0.05$.

Results: Prehypertension was detected in $26 \%$ of the students and overweight frequency was higher than the national average ( $38 \%$ for girls and $20 \%$ for boys). Concerning eating behavior, students' nutritional habits were "very good" in $7 \%$, "regular" in $68 \%$, and "poor" in $24 \%$. In bivariate analyses, systolic blood pressure and blood pressure percentile were positively associated with body mass index. In multivariate analyses, there were positive associations between eating behavior and body mass index with diastolic blood pressure: when body mass index was high and the eating behavior score was low (unhealthy eating habits), diastolic blood pressure was high. No relationship was observed between blood pressure and physical activity.

Conclusions: The adolescents assessed in this study showed a high frequency of prehypertension. Body mass index was positively associated with high blood pressure, indicating that a high body mass index is a risk factor for the development of hypertension among adolescents. Therefore, early intervention to control body mass index may be a valuable strategy to prevent overweight, obesity, and hypertension.

KEY WORDS: adolescent health; blood pressure; eating behavior; feeding behavior; nutritional status; body mass index; physical activity.

\section{RESUMO}

Objetivos: Este estudo procurou analisar a pressão arterial e suas associações com comportamento alimentar, atividade física e índice de massa corporal em estudantes do ensino médio.

Métodos: Um estudo transversal foi conduzido com estudantes do ensino médio do Centro-Oeste do Brasil. A pressão arterial foi mensurada de acordo com as diretrizes da Sociedade Brasileira de Cardiologia. O estado nutricional foi classificado de acordo com o Sistema de Vigilância Alimentar Nutricional (SISVAN), com base nos critérios de referência do National Health and Nutritional Examination Survey (NHANES II); e o nível de atividade física foi avaliado por meio do Questionário Internacional de Atividade Física, Forma Curta. O teste do Qui quadrado e o teste de Mann-Whitney foram usados para as comparações entre os gêneros e os sujeitos com pressão arterial normal e pré-hipertensão. As associações entre pressão arterial, atividade física e comportamento alimentar foram avaliadas pelos testes de regressão bivariada e multivariada. O nível de significância estabelecido foi de $\mathrm{p}<0,05$.

Resultados: Foi detectada pré-hipertensão em $26 \%$ dos estudantes e a frequência de sobrepeso foi maior do que a média nacional, $38 \%$ em meninas e $20 \%$ em meninos. Em relação ao comportamento alimentar, foram encontrados $7 \%$ de estudantes com hábitos "muito bons", $68 \%$ "regulares" e $24 \%$ com hábitos nutricionais "ruins". Nas análises bivariadas, a pressão arterial sistólica e o percentil da pressão arterial associaram-se positivamente com índice de massa corporal. Nas análises multivariadas houve associação positiva entre comportamento alimentar e índice de massa corporal com pressão arterial diastólica: quando o índice de massa corporal era alto e o escore nutricional era baixo (hábitos alimentares não saudáveis), a pressão arterial diastólica era alta. Não foi observada relação entre pressão arterial e nível de atividade física.

Conclusões: Os adolescentes incluídos no estudo apresentaram alta frequência de pré-hipertensão. O índice de massa corporal associouse positivamente com pressão arterial, de forma que o índice de massa corporal elevado pode ser considerado como fator de risco para o desenvolvimento de hipertensão arterial em adolescentes. Assim, a intervenção precoce para controlar o índice da massa corporal pode ser uma estratégia valiosa para prevenir o sobrepeso, a obesidade e a hipertensão arterial.

DESCRITORES: saúde do adolescente; pressão arterial; comportamento alimentar; estado nutricional; índice de massa corporal; atividade física. 
Abbreviations: HBP, high blood pressure; BMI, body mass index; DBP, diastolic blood pressure; SBP, systolic blood pressure; IPAQ-SF, International Physical Activity Questionnaire-Short Form; SISVAN, Sistema de Vigilancia Alimentar Nutricional; NHANES II, National Health and Nutritional Examination Survey.

\section{INTRODUCTION}

High blood pressure (HBP), one of the main risk factors for the development of cardiovascular diseases, is a growing public health concern. In contrast to developed countries, where the control of HBP and related diseases has improved, in developing countries such as Brazil, the prevalence of this condition has been progressively increasing [1] deficient strategies of primary healthcare are the major obstacles for blood pressure control. Furthermore, the epidemiology of hypertension and related diseases, healthcare resources and priorities, the socioeconomic status of the population vary considerably in different countries and in different regions of individual countries. Considering the low rates of blood pressure control achieved in Latin America and the benefits that can be expected from an improved control, it was decided to invite specialists from different Latin American countries to analyze the regional situation and to provide a consensus document on detection, evaluation and treatment of hypertension that may prove to be cost-utility adequate. The recommendations here included are the result of preparatory documents by invited experts and a subsequent very active debate by different discussion panels, held during a 2-day sessions in Asuncion, Paraguay, in May 2008. Finally, in order to improve clinical practice, the publication of the guidelines should be followed by implementation of effective interventions capable of overcoming barriers (cognitive, behavioral and affective. It is projected that $75 \%$ (or 1.17 billion) of people with HBP in the world will be living in emerging nations by 2025 [2].

It has been suggested that HBP may start in childhood or in fetal life. Prenatal factors related to maternal and/or fetal nutrition, as well as low birth weight, have been linked to heart problems in adults and increased blood pressure levels during childhood [3]. Furthermore, elevated blood pressure established early in life appears to be associated with premature development of other metabolic disorders, such as hypercholesterolemia and insulin resistance, factors that are usually caused by obesity and unhealthy eating habits [4-6]. Therefore, early diagnosis of HBP among children and adolescents could increase the possibility of interventions to improve quality of life and inhibit the development of cardiovascular diseases.

Changes in lifestyle, such as poor eating habits [7,8], physical inactivity [9], and consequent obesity, appear to be key contributing factors to HBP. Besides sedentary lifestyle, high consumption of processed and high-calorie foods has been reported as a leading factor for increased prevalence of HBP in western societies $[10,11]$ obesity among adults and overweight among children and adolescents have increased markedly since 1980. Among adults, obesity is defined as a body mass index of 30 or greater. Among children and adolescents, overweight is defined as a body mass index for age at or above the 95th percentile of a specified reference population. In 2003-2004, 32.9\% of adults 20-74 years old were obese and more than $17 \%$ of teenagers (age, 12-19 y. However, it has not been determined whether eating behavior or physical activity plays a major role in the increase of blood pressure in each population.

Although HBP has been recognized as a major risk factor for cardiovascular morbidity and mortality worldwide, there is a lack of studies on HBP in most emerging countries, in particular in the school-age population. Therefore, this study aimed to evaluate blood pressure and its association with body mass index (BMI), eating behavior, and physical activity in high school students from public schools located in midwestern Brazil.

\section{METHODS}

This cross-sectional study was approved by the Research Ethics Committee of the Federal University of Goiás (protocol no. 221/12), and conducted in Jataí, Goiás State, Brazil, from March to September 2014. After the invitation from the Municipal Department of Education, researchers from the Biological Sciences Research Group of the Federal University of Goiás presented the project to school boards and invited the schools to participate. Two schools agreed to participate in the study. The sample was selected by convenience. The inclusion criteria were students aged 14 to 19 years who agreed to participate in the study and returned the informed consent, signed by themselves or by their guardians, when they were under age. The exclusion criteria were pregnancy, routine use of medication, and reduced motor skills.

All anthropometric measurements, blood pressure assessments, and the interviews were carried out by the same researchers (undergraduate students from 
the Biological Sciences Department and professors of physiology from the Federal University of Goiás, previously trained for the procedures). Blood pressure was measured with an aneroid sphygmomanometer (BIC, AP0702, Indústria Bic de Aparelhos Médicos Ltda., Itupeva, Brazil) with the participants sitting in the upright position (without their legs crossed), with the left arm at the heart level. Both systolic blood pressure (SBP) and diastolic blood pressure (DBP) were measured three times in the left arm at a 2-minute interval between measurements. The first, second, and third measurements were taken after 5 , 7 , and 9 minutes of resting. The mean values of these measurements were considered for statistical purposes. The VI Brazilian Guidelines on Hypertension were used for HBP definition [12]. Students with SBP or DBP above the 95th percentile for sex, age, and height were considered hypertensive, whereas prehypertension was defined as an SBP and/or DBP $\geq 90$ th percentile but $<95$ th percentile [12].

The body weight of participants (lightly dressed) was assessed using a calibrated electronic scale (Glicomed, Accumed-Glicomed Ltda., Rio de Janeiro, Brazil). Height was measured in bare or stocking feet with the student standing upright against a Holtain stadiometer (Holtain Ltd., Crymych, UK). BMI was calculated as body weight $(\mathrm{kg})$ divided by height $\left(\mathrm{m}^{2}\right)$, as described in previous studies $[13,14]$.

Eating behavior was classified according to the Brazilian Food and Nutrition Surveillance System (Sistema de Vigilancia Alimentar Nutricional, SISVAN) [15]. SISVAN is the information system of the Brazilian Ministry of Health, whose purpose is to provide the necessary rationale for decisions on food and nutrition actions and health promotion. For the diagnosis of nutritional status, SISVAN uses the BMI percentile for age and sex as classification criterion according to the standard reference of the National Health and Nutritional Examination Survey (NHANES II) [16]. A validated questionnaire about eating behavior, adapted for the Brazilian population, was used for nutritional classification and adequacy according to the Department of Primary Healthcare of the Brazilian Ministry of Health [15]. The questionnaire [17] is answered online and uses the following scores: up to 28 points: poor; 29 to 42 points: regular; 43 points or more: very good.

Physical activity was assessed by the International Physical Activity Questionnaire - Short Form (IPAQSF) [18] and determined by self-reported frequency (number of times per week), intensity (strong, moderate, and weak), and duration (minutes per day) of each type of physical activity performed. In this context, physical activity was classified as leisuretime, sports-related, transport-related, and activities of daily living.

The students were classified into the following four groups according to physical activity: 1) up to 5 points: sedentary - participants that reported no involvement with any physical activity for at least 10 consecutive minutes during the week; 2) 6 to 10 points: poorly active - participants that reported performing some physical activity, but not enough to be considered active; 3) 11 to 15 points: active - participants that reported practicing moderate physical activity for at least 5 times a week for at least 30 minutes a day, or vigorous activity for 20 minutes at least 3 times a week; 4) 16 to 20 points: very active - participants that reported practicing moderate physical activity for at least 5 times a week for at least 30 minutes a day plus vigorous activity for 20 minutes for at least 3 times a week.

The chi-square test was used for the evaluation of blood pressure, nutritional status, eating behavior, and physical activity. As normal distribution was not verified by the Shapiro-Wilk test, the Mann-Whitney $\mathrm{U}$ test was used for comparisons between genders and normotensive and prehypertensive subjects. Bivariate regression was used to evaluate the isolated association of blood pressure variables (DBP, SBP, and percentile) with BMI and with eating behavior or physical activity scores. Multivariate regression analysis was performed to verify the relationship between blood pressure variables and BMI, physical activity, and eating behavior. The significance level was set at $\mathrm{p}<0.05$.

\section{RESULTS}

There were 39 schools in the urban areas of Jataí in 2014 and 2,812 students enrolled in high school during the study period [19]. In each of the two schools that agreed to participate, 190 and 599 students were respectively enrolled (total 799). The main obstacles for the assessment of students was the fact that a considerable number of teachers did not allow the application of the questionnaire during their classes and that many students lost the term of consent or did not bring it signed. Thus, 120 students were initially included in the study. The exclusion rate was $31.7 \%$ because nine students did not attend the anthropometric measurements and 11 did not answer all the questions in the questionnaire. Therefore, the final sample consisted of 82 students. 
The sample had a mean age of $16.75 \pm 1.16$ years and was comprised of $52(63 \%)$ female students. In terms of gender, there was statistical difference only in the height percentile, as males were taller than females. When the family history of high blood pressure (HBP) was analyzed, 21 (26\%) students reported the presence of this condition among their family members (e.g., uncle or cousin), but only one student had hypertensive parents. No students reported having siblings with HBP.

Concerning blood pressure measurement, $73 \%$ of female students were normotensive and $27 \%$ were prehypertensive, while $73 \%$ of male students were normotensive and $23 \%$ were prehypertensive. One boy was classified as hypertensive stage 1 . High occurrence of regular nutritional status was identified among males. No difference in nutritional status was found among females, with overweight frequencies of $38 \%$ and $20 \%$ in females and males, respectively. Eating behavior was analyzed in accordance with the scores obtained from the "How is your diet?" ("Como está sua alimentação?" in Portuguese) questionnaire [17]. According to the scores, there was high occurrence of both male and female students classified into the "regular" feeding category (Table 1).
In qualitative analyses, the daily consumption of fruits $(81 \%)$, vegetables $(77 \%)$, water $(83 \%)$, and fish $(61 \%)$ was deemed inadequate, while the ingestion of sausages and fried food was higher than that recommended (56\%) by the Department of Primary Healthcare [15]. Additionally, the students reported poor eating habits, including the consumption of sweets and soft drinks every day (69\%), intake of whole milk (78\%), and no habit of reading the information on nutritional contents (76\%). Among appropriate habits, $56 \%$ reported consuming adequate amounts of meat and eggs, 64\% declared they removed visible fat from meat and skin from chicken, $81 \%$ reported using vegetable oil to prepare food, $77 \%$ did not add salt to their food after it was served, and $89 \%$ did not consume alcohol. Additionally, there was no statistical difference in the total score for eating behavior between prehypertensive and normotensive students $(p=0.55)$.

The physical activity scores are presented in Table 1. Most participants were classified as having an "active" level of physical activity. There was a low frequency of students categorized as "sedentary" $(6 \%)$. There was no statistical difference in the level of physical activity among prehypertensive and normotensive students $(\mathrm{p}=0.28)$ or between genders $(\mathrm{p}=0.88)$.

Table 1. Blood pressure, nutritional status, eating behavior, and physical activity of students aged 14 to 19 years. Jataí, Goiás State, Brazil, March to September 2014.

\begin{tabular}{|c|c|c|c|c|c|c|c|}
\hline \multirow{2}{*}{ Variable } & \multirow{2}{*}{ Category } & \multicolumn{2}{|c|}{ Female $(\mathrm{N}=52)$} & \multicolumn{2}{|c|}{ Male $(\mathrm{N}=30)$} & \multicolumn{2}{|c|}{ Grouped $(\mathrm{N}=82)$} \\
\hline & & $N$ & $\%$ & $\mathbf{N}$ & $\%$ & $\mathbf{N}$ & $\%$ \\
\hline \multicolumn{8}{|l|}{ Blood pressure } \\
\hline$<90$ th percentile & Normal & 38 & $73^{*}$ & 22 & $73^{*}$ & 60 & $73 *$ \\
\hline$\geq 90$ th to $<95$ th percentile & Prehypertension & 14 & 27 & 7 & 23 & 21 & 26 \\
\hline$>95$ th percentile & Stage 1 hypertension & - & - & 1 & 3 & 1 & 1 \\
\hline \multicolumn{8}{|l|}{ Body mass index } \\
\hline$<5$ th percentile & Underweight & 6 & 12 & 6 & 20 & 12 & 15 \\
\hline$\geq 5$ th to $<85$ th percentile & Normal & 26 & $50^{\S}$ & 18 & $60^{\#}$ & 44 & $54^{ \pm}$ \\
\hline$\geq 85$ th percentile & Overweight/obese & 20 & 38 & 6 & 20 & 26 & 32 \\
\hline \multicolumn{8}{|l|}{ Eating behavior } \\
\hline Up to 28 points & Poor habits & 14 & 27 & 6 & 20 & 20 & 24 \\
\hline 29 to 42 points & Regular & 34 & $65^{+}$ & 22 & $73^{+}$ & 56 & $68^{+}$ \\
\hline 43 points or more & Very good & 4 & 8 & 2 & 7 & 6 & 7 \\
\hline \multicolumn{8}{|l|}{ Physical activity } \\
\hline Up to 5 points & Sedentary & 1 & 2 & 3 & 10 & 4 & 5 \\
\hline 6 to 10 points & Poorly active & 9 & 17 & 8 & 27 & 17 & 21 \\
\hline 11 to 15 points & Active & 28 & $54^{\ddagger}$ & 10 & 33 & 38 & $46^{\ddagger}$ \\
\hline 16 to 20 points & Very active & 14 & 27 & 9 & 30 & 23 & 28 \\
\hline
\end{tabular}

Chi-square test.

Blood pressure: ${ }^{*} \mathrm{p}<0.001$, normal versus prehypertension/stage 1 hypertension.

Nutritional status: $\$ p=0.002,{ }^{*} p=0.008,{ }^{£} p<0.001$, normal versus underweight/overweight.

Eating behavior: ${ }^{t} p<0.001$, regular behavior versus very good habits.

Physical activity: ${ }^{\ddagger} \mathrm{p}<0.001$, active versus poorly active/sedentary. 
Table 2. Associations between percentile, systolic or diastolic blood pressure, body mass index, physical activity, and eating behavior, in students aged 14 to 19 years. Jataí, Goiás State, Brazil, March to September 2014.

\begin{tabular}{|c|c|c|c|c|c|c|}
\hline & \multicolumn{2}{|c|}{ Blood pressure percentile } & \multicolumn{2}{|c|}{ Systolic blood pressure } & \multicolumn{2}{|c|}{ Diastolic blood pressure } \\
\hline & $\beta(95 \% \mathrm{Cl})$ & p & $\beta(95 \% \mathrm{Cl})$ & p & $\beta(95 \% \mathrm{Cl})$ & p \\
\hline \multicolumn{7}{|l|}{ Bivariate linear regression } \\
\hline Body mass index & $1.22(0.25,2.19)$ & $0.004 *$ & $0.90(0.30,1.48)$ & $0.03 *$ & $0.56(-0.03,1.09)$ & 0.06 \\
\hline Physical activity & $0.43(-0.66,1.53)$ & 0.79 & $0.28(0.30,1.48)$ & 0.84 & $-0.51(-1.17,0.18)$ & 0.15 \\
\hline Eating behavior & $0.16(-0.38,0.72)$ & 0.60 & $0.04(-0.28,0.34)$ & 0.18 & $0.25(-0.18,0.55)$ & 0.32 \\
\hline \multicolumn{7}{|l|}{ Multivariate linear regression } \\
\hline Physical activity \& body mass index & $0.52(-0.09,0.15)$ & 0.65 & $-0.06(-0.17,0.03)$ & 0.17 & $0.02(-0.24,0.13)$ & 0.56 \\
\hline Eating behavior $\&$ body mass index & $0.01(-0.12,0.13)$ & 0.94 & $0.01(-0.56,0.08)$ & 0.37 & $0.06(0.01,0.11)$ & $0.013 *$ \\
\hline Eating behavior, body mass index \& Physical activity & $0.01(-0.02,0.05)$ & 0.86 & $-0.01(-0.01,0.02)$ & 0.78 & $0.01(-0.02,0.01)$ & 0.41 \\
\hline
\end{tabular}

$\beta=$ regression coefficient; $\mathrm{Cl}=$ confidence interval.

Among prehypertensive students, 50\% were overweight, $5 \%$ were sedentary, $25 \%$ were poorly active, $60 \%$ were active, and $10 \%$ were very active. Prehypertensive students had a significantly higher BMI than normotensive ones $(26.8 \pm 7.5$ vs. $21.2 \pm 4.0$, $\mathrm{p}<0.001)$. Regarding the eating behavior of prehypertensive students, $77 \%$ reported having "regular" habits, $9 \%$ "poor" habits, and 14\% "very good" habits. The student identified as HBP stage 1 had a normal BMI percentile, was classified as active, and had a regular eating behavior, but his parents were hypertensive.

Bivariate analysis was used to evaluate the association of blood pressure parameters with isolated variables of BMI, physical activity, and eating behavior scores. BMI was positively associated with blood pressure percentiles and with SBP. No relationship was found between eating behavior or physical activity scores and blood pressure parameters (blood pressure percentile, DPB, and SBP). Also, no association was found between BMI and physical activity and eating behavior scores (data not shown). Multivariate regression analysis, used to verify the association of blood pressure variables with physical activity, eating behavior, and BMI, identified that eating behavior and BMI together were associated with DBP: when BMI was high and the nutritional score was low, DBP was high. No other associations were identified by the multivariate regression analysis in this study (Table 2).

\section{DISCUSSION}

HBP is one of the risk factors for the development of cardiovascular diseases, which is the leading cause of death in western populations [20], and recent reports have suggested that this alarming disease could be developed during childhood and adolescence [21-24].
The present study evaluated the frequency of HBP and the associations between blood pressure, BMI, and two behaviors linked to HBP (eating behavior and physical activity), and found that high BMI and blood pressure parameters were associated. In addition, high BMI and poor eating behavior were associated with increased DBP. Since eating behavior was not associated with blood pressure in the univariate analysis, this association probably occurred because of the strong association of HBP with high BMI. By contrast, no association was detected between physical activity and blood pressure.

The fact that the analyzed sample presented a high frequency of prehypertension, higher than that found in other studies from Brazil and from other countries [21-25], is noteworthy. Perhaps, these characteristics and behaviors are key to understanding the early development of HBP in some populations. In addition, the high frequency of overweight was also higher than the average found in Brazilian students [26-28], particularly among females, although the majority of students were classified as physically active and had a regular eating behavior. Despite the lack of a relationship between blood pressure and the level of physical activity or eating behavior alone, there was an association between HBP and BMI, and between DBP and BMI with poor eating behavior.

Unhealthy eating behaviors and physical inactivity are well described as major causes of overweight, metabolic diseases, and HBP [29-31]. In this study, most of the students presented a satisfactory level of physical activity. Moreover, the frequency of sedentary behavior was very low when compared to other studies [32,33]. Regarding eating behavior, "regular" dietary habits prevailed. However, healthy dietary practices such as high consumption of fruits and vegetables, 
as well as of low fat, salt, and refined carbohydrates, were not common, in agreement with other studies that applied the same survey [34,35]. Actually, despite the predominance of students with regular eating behaviors, the prevalence of students with an unhealthy lifestyle was higher than what is recommended by the Brazilian Ministry of Health [15].

Although different studies have suggested that changes in blood pressure are mediated by physical activity, BMI, and eating behavior [30,36], our results only showed a direct association between BMI and blood pressure parameters. Moreover, the BMI of prehypertensive students was higher than that of non-hypertensive ones, in agreement with previous findings [23,24]. Additionally, when eating behavior and BMI were assessed together, there was an association with DBP, whereas students with lower BMI and a high nutritional score had low DBP. No association with blood pressure was found when physical activity was analyzed together with BMI and/or eating behavior. As a matter of fact, when the eating behavior and BMI of prehypertensive students were evaluated, $62 \%$ had excessive body mass even though most of them had been classified as physically active. We believe that the lack of association between physical activity and other variables has to do with the weakness of the IPAQ-SF. This issue was addressed by Lee et al. (2011) [37] in their review of 23 studies that compared the results of the IPAQ-SF with those of other instruments. They suggested that the IPAQ-SF overestimates the level of physical activity. This idea was also supported by other studies [38,39]. Therefore, the use of other questionnaires or equipment that directly assess daily movement (e.g., accelerometer) [30] could provide more accurate measurements, leading to better conclusions about the effect of physical activity on blood pressure.

Early identification of prehypertension in children and adolescents could be key to inhibiting the development of HBP. The present data suggest that BMI was a good predictor of prehypertension in students aged 14 to 19 years. Moreover, the high frequency of prehypertension compared to the national average seems to be related to the high rates of overweight students. Therefore, educational programs could be an effective strategy to prevent the increase of BMI and the further occurrence of high blood pressure among children and adolescents.

\section{NOTES}

Acknowledgm0ents

The researchers thank the Municipal Department of Health of Jataí, Goiás State, Brazil, and in particular Lucila Ferri Pessuti, for helping with the logistics of data collection.

Financial support

This study was financially supported by the Brazilian National Council of Scientific and Technological Development (CNPq). Grant 301744/2014-9.

Conflicts of interest disclosure

The authors declare no potential conflicts of interest relevant to the contents of this study.

\section{REFERENCES}

1. Sanchez RA, Ayala M, Baglivo H, Velazquez C, Burlando G, Kohlmann O, Jimenez J, Jaramillo PL, Brandao A, Valdes G, Alcocer L, Bendersky M, Ramirez AJ, Zanchetti A. Latin American guidelines on hypertension. Latin American Expert Group. J Hypertens. 2009 May;27(5):905-22. http://dx.doi.org/10.1097/HJH.0b013e32832aa6d2

2. Picon R V, Fuchs FD, Moreira LB, Riegel G, Fuchs SC. Trends in prevalence of hypertension in Brazil: a systematic review with metaanalysis. PloS one, San Fr. 2012;7:e48255. http://dx.doi.org/10.1371/journal.pone.0048255

3. Franco MC, Christofalo DM, Sawaya AL, Ajzen SA, Sesso R. Effects of low birth weight in 8- to 13-year-old children: implications in endothelial function and uric acid levels. Hypertension. 2006 July;48(1):45-50. http://dx.doi.org/10.1161/01.HYP.0000223446.49596.3a

4. Pedrozo W, Rascón MC, Bonneau G, Pianesi MI De, Olivera CC, Aragón SJ De, Ceballos B, Gauvry G. Síndrome metabólico y factores de riesgo asociados con el estilo de vida de adolescentes de una ciudad de Argentina, 2005. Rev Panam Salud Pública. 2008;24(3):149-60. http://dx.doi.org/10.1590/S1020-49892008000900001

5. NIH. The Fourth Report on the Diagnosis, Evaluation, and Treatment of High Blood Pressure in Children and Adolescents. Natl Institutes Heal. 2005;05-5267:1-60

6. Coutinho RX, Santos WM Dos, Folmer V, Puntel RL. Prevalência de comportamentos de risco em adolescentes. Cad Saude Coletiva. 2013;21(4):441-9. http://dx.doi.org/10.1590/S1414-462X2013000400013 
7. Dishchekenian VRM, Escrivão MAMS, PalmaI D, Ancona-LopezI F, AraújoII EAC de, TaddeiI JA de AC. Padrões alimentares de adolescentes obesos e diferentes repercussões metabólicas. Rev Nutr. 2011;24:17-29. http://dx.doi.org/10.1590/S1415-52732011000100002

8. Ministério da Saúde (BR). Guia alimentar para a população brasileira. Brasília: Ministério da Saúde; 2008.

9. Palatini P. Cardiovascular effects of exercise in young hypertensives. Int J Sports Med. 2012 Sept;33(9):683-90. http://dx.doi. org $/ 10.1055 / \mathrm{s}-0032-1304633$

10. Ogden CL, Yanovski SZ, Carroll MD, Flegal KM. The epidemiology of obesity. Gastroenterology. 2007;132(6):2087-102. http://dx.doi org/10.1053/j.gastro.2007.03.052

11. Delva J, O'Malley PM, Johnston LD. Health-related behaviors and overweight: a study of Latino adolescents in the United States of America. Rev Panam Salud Publica. 2007;21(1):11-20. http://dx.doi.org/10.1590/S1020-49892007000100002

12. Sociedade Brasileira de Cardiologia; Sociedade Brasileira de Hipertensão; Sociedade Brasileira de Nefrologia. VI Brazilian Guidelines on Hypertension. Arq Bras Cardiol. 2010 July;95(1 Suppl):1-51.

13. Ferreira NS, Lira CAB, Ferri LP, Cintra C, Morais L, Gonçalves VO, Benite-Ribeiro SA. Abordagem Multiprofissional no Cuidado à Saúde de Pacientes do Programa HIPERDIA. Rev Bras Hiper. 2014;21(1):31-7.

14. Physical status: the use and interpretation of anthropometry. Report of a WHO Expert Committee. World Heal Organ Tech Rep Ser. $1995 ; 854: 1-452$.

15. Basil MS. Vigilância alimentar e nutricional - Sisvan: orientações básicas para a coleta, processamento, análise de dados e informação em serviços de saúde. Brasília: Ministério da Saúde; 2004.

16. National Center for Health Statistics. National Health and Nutrition Examination Survey: Analytic Guidelines, 1999-2010. Hyattsville: DHHS; 2013.

17. Ministério da Saúde (BR). Como está a sua alimentação? [Internet]. Vol. 1. 2006 [cited 2016]. p. 6-7. Available from: http://dab.saude. gov.br/portaldab/teste_alimentacao.php

18. Matsudo S, Araujo T, Matsudo V, Andrade D, Andrade E, Oliveira LC, Braggion G. Questionário Internacional de Atividade Física (I PAQ): Estudo de Validade e Reprodutibilidade no Brasil. Rev Bras Ativ Fís Saúde. 2001;6(2):1-14.

19. Matrículas e infraestrutura [Internet]. 2014 [cited 2016]. Available from: http://www.qedu.org.br/estado/105-bahia/censo-escolar?year= $2014 \&$ dependence $=0 \&$ localization $=0 \&$ education_stage $=0 \&$ item $=$

20. World Health Organization. Prevention of Cardiovascular Disease - Guidelines for assessment and management of cardiovascular risk. Geneva: WHO; 2007.

21. Cao ZQ, Zhu L, Zhang T, Wu L, Wang Y. Blood pressure and obesity among adolescents: a school-based population study in china. Am J Hypertens. 2012;25(5):576-82. http://dx.doi.org/10.1038/ajh.2012.5

22. Silva AC, Rosa AA. Blood pressure and obesity of children and adolescents association with body mass index and waist circumference. Arch Latinoam Nutr. 2006;56(3):244-50.

23. Pinto SL, Silva RCR, Priore SE, Assis AMO, Pinto EJ. Prevalência de pré-hipertensão e de hipertensão arterial e avaliação de fatores associados em crianças e adolescentes de escolas públicas de Salvador, Bahia, Brasil. Cad Saude Publica. 2011;27(6):1065-75. http://dx.doi.org/10.1590/S0102-311X2011000600004

24. Rosa MLG, Fonseca VM, Oigman G, Mesquita ET. Pré-hipertensão arterial e pressão de pulso aumentada em adolescentes: prevalência e fatores associados. Arq Bras Cardiol 2006; 87:46-53. http://dx.doi.org/10.1590/S0066-782X2006001400007

25. Lo JC, Sinaiko A, Chandra M, Daley MF, Greenspan LC, Parker ED, Kharbanda EO, Margolis KL, Adams K, Prineas R, Magid D, O'Connor PJ. Prehypertension and hypertension in community-based pediatric practice. Pediatrics. 2013;131(2):e415-24. http://dx.doi. org/10.1542/peds.2012-1292

26. Romagna ES. Prevalência de sobrepeso e obesidade em crianças e adolescentes de uma unidade básica de saúde em Canoas, Rio Grande do Sul, e comparação do diagnóstico nutricional entre os gráficos do CDC 2000 e da OMS 2006. Sci Med. 2008;20(51):228-31.

27. Burgos MS, Reuter CP, Burgos LT, Pohl HH, Pauli LTS, Horta JA, Reckziegel MB, Franke SIR, Prá D, Camargo M. Uma Análise entre Índices Pressóricos, Obesidade e Capacidade Cardiorrespiratória em Escolares. Arq Bras Cardiol. 2010;94:788-93. http://dx.doi. org/10.1590/S0066-782X2010005000046

28. Araújo TL, Lopes MVO, Cavalcante TF, Guedes NG, Moreira RP, Chaves ES, Silva VM. Análise de indicadores de risco para hipertensão arterial em crianças e adolescentes. Rev Esc Enferm USP. 2008;42:120-6. http://dx.doi.org/10.1590/S0080-623420080001 00016

29. Souza CO, Silva RCR, Assis AMO, Fiaccone RL, Pinto E de J, Moraes LTLP. Association between physical inactivity and overweight among adolescents in Salvador, Bahia--Brazil. Rev Bras Epidemiol. 2010;13(3):468-75. http://dx.doi.org/10.1590/S1415-790X2010000300010

30. Gaya AR, Alves A, Aires L, Ribeiro C, Mota J, Martins CL. Association between time spent in sedentary, moderate to vigorous physical activity, body mass index, cardiorespiratory fitness and blood pressure. Ann Hum Biol. 2009 Jul-Aug;36(4):379-87. http://dx.doi org/10.1080/03014460902817976

31. Santos JM, Tewari S, Benite-Ribeiro SA. The effect of exercise on epigenetic modifications of PGC1: The impact on type 2 diabetes. Med Hypotheses. 2014 Jun;82(6):748-53. http://dx.doi.org/10.1016/j.mehy.2014.03.018

32. Ceschini FL, Andrade DR, Oliveira LC, Araujo Junior JF, Matsudo VK. Prevalence of physical inactivity and associated factors among high school students from state's public schools. J Pediatr (Rio J). 2009;85:301-6. http://dx.doi.org/10.1590/S0021-75572009000400006

33. Bergier J, Kapka-Skrzypczak L, Biliński P, Paprzycki P, Wojtyła A. Physical activity of Polish adolescents and young adults according to IPAQ: A population based study. Ann Agric Environ Med. 2012;19:109-15. 
34. Cimadon HMS, Geremia R, Pellanda LC, Maria H, Cimadon S. Dietary habits and risk factors for atherosclerosis in students from Bento Gonçalves (state of Rio Grande do Sul). Arq Bras Cardiol. 2010;95:166-72. http://dx.doi.org/10.1590/S0066-782X2010005000088

35. Feitosa EPS, Dantas CAO, Andrade-Wartha RES, Marcellini PS, Mendes-Netto RS. Hábitos Alimentares de Estudantes de uma Universidade Pública no Nordeste, Brasil. Alim Nutr. 2010;21(2):225-30.

36. Rizzo N, Ruiz Jo, Hurtig-Wennlof A, Ortega F, Sjostrom M. Relationship of physical activity, fitness, and fatness with clustered metabolic risk in children and adolescents: the European youth. J Pediatr. 2007 Apr;150(4):388-94. http://dx.doi.org/10.1016/j.jpeds.2006.12.039

37. Lee PH, Macfarlane DJ, Lam T, Stewart SM. Validity of the international physical activity questionnaire short form (IPAQ-SF): A systematic review. Int J Behav Nutr Phys Act. 2011 Oct 21;8:115. http://dx.doi.org/10.1186/1479-5868-8-115

38. Grimm EK, Swartz AM, Hart T, Miller NE, Strath SJ. Comparison of the IPAQ-short form and accelerometry predictions of physical activity in older adults. J Aging Phys Act. 2012;20:64-79. http://dx.doi.org/10.1123/japa.20.1.64

39. Rangul V, Holmen TL, Kurtze N, Cuypers K, Midthjell K. Reliability and validity of two frequently used self-administered physical activity questionnaires in adolescents. BMC Med Res Methodol. 2008;8:47. http://dx.doi.org/10.1186/1471-2288-8-47 